Article

\title{
Governing Precarious Immigrant Workers in Rural Localities: Emerging Local Migration Regimes in Portugal
}

\author{
Inês Cabral and Thomas Swerts * \\ Department of Public Administration and Sociology, Erasmus School of Social and Behavioural Sciences, \\ Erasmus University Rotterdam, The Netherlands; E-Mails: inescsmc@gmail.com (I.C.), swerts@essb.eur.nl (T.S.) \\ * Corresponding author
}

Submitted: 11 May 2021 | Accepted: 16 August 2021 | Published: 28 October 2021

\begin{abstract}
Over the last decades, the globalization of the food and agriculture sector has fueled international labor migration to rural areas in Southern Europe. Portugal is no exception to this trend, as the intensification of foreign investment in agriculture combined with a declining and ageing workforce created a demand for flexible immigrant labor. The Eastern European and Asian immigrant workers who answered the industry's call were confronted with poor working conditions and lacking access to public services. In this article, we zoom in on the governance challenge that the presence of precarious immigrant workers (PIWs) poses to rural municipalities in the south of Portugal. The burgeoning literature on local integration policies mainly focuses on how cities deal with the challenge posed by international labor migration. This article draws on a detailed case study of the municipality of Odemira to argue that more attention needs to be paid to emerging local migration regimes in non-urban localities. By adopting a regime-theoretical approach, we study how power relations between the local government, civil society, and the private sector play out around the question of immigrant reception. Our study suggests that immigration policies in rural localities are increasingly being developed through cooperation and coproduction between public and private actors. First, we demonstrate how the presence of PIWs is perceived as a policy "problem" by each actor. Second, we outline how a governing coalition formed around the shared concern to improve arrival infrastructures, stimulate integration, mediate socio-cultural impact, and accommodate business interests. We conclude by critically questioning the impact that emerging local migration regimes have on the rights and social position of PIWs in rural contexts.
\end{abstract}

\section{Keywords}

globalization; governance; immigrants; local impacts; precarious workers; rural localities

\section{Issue}

This article is part of the issue "Migration and Refugee Flows: New Insights" edited by Inmaculada Martínez-Zarzoso (University of Göttingen, Germany / Jaume I University, Spain).

(C) 2021 by the authors; licensee Cogitatio (Lisbon, Portugal). This article is licensed under a Creative Commons Attribution 4.0 International License (CC BY).

\section{Introduction}

Over the last decades, the globalization of the food and agriculture sector has fueled international labor migration (ILM) to rural areas in Southern Europe. Portugal is no exception to this trend. Foreign investment in intensive agriculture has dramatically increased in Portugal since the 1980s (Pereira et al., 2016). At the same time, workers from Portuguese origin have been increasingly unwilling to accept the poor working conditions and low wages that characterize work in the sector (Fonseca, 2008). Together with an ageing population, this has created a demand from agricultural companies for cheap and flexible immigrant labor (Sampaio \& Carvalho, 2016). As a result, rural areas in the south like Alentejo, where intensive agriculture like berry cultivation tends to be located, have become primary destinations for precarious immigrant workers (PIWs; Fonseca, 2008). We deliberately use the term "precarious immigrant workers" here to underscore both the vulnerability, job insecurity, 
low pay, and lack of union representation that characterizes their working conditions and the precarity, deportability, and illegality that characterizes their legal status (Goldring \& Landolt, 2012; Thornley et al., 2010).

In this article, we zoom in on the case of Odemira, the largest municipality in the region, to investigate the governance challenges that the increase and diversification of the immigrant population pose for local actors. In 2018, 6124 out of 24,621 residents in Odemira, or about $25 \%$ of the total population, were migrants who respectively originated from Bulgaria $(1,098)$, Nepal $(1,015)$, Thailand (825), and India (795; PORDATA, 2018a). Given the substantial amount of PIWs with a precarious legal status, it is fair to say that these numbers are an under-estimation. When asked if the municipality felt ready to adequately organize the reception of these PIWs, the mayor stated that: "The territory is not prepared to meet the demands caused by the new agriculture regarding the provision of housing for immigrants, infrastructure, social development, cultural integration and population growth in such a small period of time" (Dias, 2019). Indeed, the Eastern European and Asian immigrant workers who answered the industry's call were generally confronted with lacking access to public services and poor working conditions (Faget, 2018). Compared to PIWs who arrive and settle themselves in urban localities, immigrants in non-urban localities also have less support from established immigrant organizations and communities that they can rely on.

Since its inception, the field of migration studies has been biased towards investigating how national governments shape governance responses to international migration (see Wimmer \& Glick-Schiller, 2002). In part inspired by the increasing challenges that cities face to grapple with the everyday reality of locally accommodating stranded refugees and undocumented migrants, migration studies have made a significant local turn. As Zapata-Barrero et al. (2017, p. 241) argue, the starting point for this shift in perspective is the acknowledgement that "cities and regions... are becoming more and more active agents, drawing their own agenda, policy strategies and key questions/answers to challenges related to integration and diversity accommodation." While recent scholarship has clarified the leading role that "arrival infrastructures" (Meeus et al., 2019) and "sanctuary cities" (Bauder, 2017) play in terms of developing inclusive accommodation and integration policies towards immigrants with precarious legal status, non-urban localities still remain under-investigated.

This study adopts a case-study design to gain a better insight into the dynamics and characteristics of emerging local migration regimes (LMRs) in rural localities (see Flyvbjerg, 2006). We mainly rely on expert interviews with representatives of the Parish Council, the Municipal Plan for Integration, agriculture workers' unions, work conditions inspection, and civil society organizations to map the positioning of the actors involved and the relations between them (see Supplementary File). Our study suggests that immigration policies in rural localities are increasingly being developed through cooperation and coproduction between public and private actors. Based on these findings, we argue that more attention needs to be paid to the characteristics and dynamics of emerg ing LMRs in non-urban localities. We borrow insights from recent scholarship in migration and urban studies (Lambert \& Swerts, 2019; Schiller, 2016; Swyngedouw, $2019,2020)$ to develop a regime-theoretical approach that helps to explain the following question: How do governmental and non-governmental actors in rural localities like Odemira perceive and respond to the local governance challenge posed by international labor migration?

In the remainder of this article, we first conceptualize the local governance response to ILM in rural localities and introduce the regime-theoretical approach adopted in this study. Second, we outline the methods used and contextualize the case of Odemira. Third, we demonstrate how the presence of PIWs was perceived as a policy "problem" by each actor. Next, we outline how a governing coalition formed around the shared concern to improve arrival infrastructures, mediate socio-cultural impact, and accommodate the interests of businesses. We conclude by critically questioning the impact that these emerging LMRs have on the rights and social position of PIWs in rural contexts.

\section{Conceptualizing the Local Governance Response to International Labor Migration in Rural Areas}

\subsection{The Globalization of Agriculture and the Rise of Precarious Immigrant Work}

In this section, we argue that economic globalization is to be held responsible for the restructuring of the agricultural sector, the intensification of ILM and the precarization of immigrant workers (see Piore, 1979; Sassen-Koob, 1981). Taken together, these three global trends help to explain the local transformation of the agricultural sector and the corresponding precarity of immigrant workers' social position in the Odemira region.

First, the increased volume of interactions and integration of the world economy has radically transformed the agricultural sector. As Robinson's (2018) review of the evidence suggests, the impact of globalization can be felt in terms of the production, organization, and industrial relations in global agriculture. Agricultural production has become more specialized and dependent on industrial-style farming methods. However, previous research has shown that mechanization is not always possible in labor-intensive industries like fruit and vegetable picking (see Martin, 1983). Smaller, familyowned businesses have made way for transnationally organized companies that continuously seek to expand their global production network and tap into new markets. Finally, globalized agricultural companies' incessant search to maximize profits and reduce costs has led them to rely on cheap immigrant labor, thereby increasing 
the asymmetry between labor and capital (Robinson, 2018, p. 135).

International migration to rural areas like Odemira therefore needs to be regarded as a direct effect of labor shortages and a response to demand from employers in Portugal's globalized agricultural sector (Fonseca, 2008; Peixoto, 2002). In his influential labor market theory, Piore (1979) has argued that segmentation into a primary (top) and secondary (bottom) labor market fuels the demand for cheap immigrant labor for jobs that are deemed too low in wages or status by primary workers. Research on immigrant employment in the agricultural sector in Southern European countries like Spain, Italy, and Portugal has revealed the significant extent to which the sector serves as a secondary labor market for immigrant workers (see Reyneri, 2004). For a long time, the sector's dependency on immigrant labor was fairly casual, whereby immigrants were recruited as temporary workers for seasonal work like harvesting. However, rising labor costs and labor shortages in part explain why the presence of PIWs in rural areas became a more permanent fixture (Reyneri, 2004).

Besides changes in the agricultural sector and shortages on the labor market, the relative vulnerability of immigrant workers also needs to be considered to explain their increased presence in rural areas like Odemira. As Sassen-Koob has put it, the desirability of immigrant workers is narrowly interwoven with their vulnerability, because "immigrants are not necessarily that much cheaper than low-wage national workers; it is also their powerlessness which makes them profitable" (1981, p. 72). Indeed, previous research has shown that many immigrant workers in the agricultural sector have a precarious legal status referring to "forms of legal status characterized by any of the following: lack of permanent residence or permanent work authorization, limited or no social benefits, inability to sponsor relatives and deportability" (Goldring \& Landolt, 2012, p. 12). What makes the impact of precarious legal status on PIWs' lives even more unpredictable is that they may be "spatially, juridically and substantively discontinuous" and can include "indefinite and unpredictable periods of living with temporary authorized and/or unauthorized precarious status" (Goldring \& Landolt, 2021, p. 1). This unpredictability and uncertainty in turn makes PIWs especially vulnerable for job exploitation, violence, and other forms of abuse. Furthermore, PIWs who accept to do the "dirty work" that others refuse to do, often lack the linguistic and other skills to protest their conditions and tend to be non-unionized (Cole \& Booth, 2007).

\subsection{The Local Turn in Migration Governance}

In the previous section, we argued that the globalization of the agricultural sector helps to explain the intensification and precarization of immigrant work in the Odemira Region. However, the political initiatives and governance arrangements that emerge in response to ILM simulta- neously need to be taken into consideration. In this context, the booming literature on the local turn in migration governance offers pointers (Zapata-Barrero et al., 2017). As governance involves the interaction between public and private sector and negotiation mechanisms between them (Schiller, 2018), local governance focuses on the interaction of local actors and their political agenda (Zapata-Barrero et al., 2017). Research suggests that urban governments and local civil society have gained in importance as active agents that shape immigrant reception and integration (De Graauw, 2016; Swyngedouw, $2019,2020)$. Since cities are places of arrival, transit, and destination for PIWs, local actors need to develop "arrival infrastructures," referring to "those parts of the urban fabric within which newcomers become entangled on arrival, and where their future local or translocal social mobilities are produced as much as negotiated" (see Meeus et al., 2019, p. 34). In many "hospitable" cities, policy makers and activists have responded to this challenge by taking initiatives and developing policy measures aimed at making social and cultural services more accessible and ensuring local immigrant rights (De Graauw \& Bloemraad, 2017; Lambert \& Swerts, 2019).

One of the main contributions this literature has made is to demand attention to the local dynamics of cooperation that emerge between public and private partners in urban settings. Swyngedouw, for example, has argued that institutionalized urban coalitions in the field of migrant reception compete to reel in newcomers as to "influence the political-cultural demographics of the city and destabilize the linguistic power balance in Brussels" (2020, p. 395). Others, like De Graauw and Bloemraad (2017, p. 115) suggest that local immigration governance often involves cooperation in the shape of public-private partnerships that produce policy innovation, immigrant leadership development, and improved service delivery to immigrant communities. Finally, Schiller (2018) argues that such partnerships can involve relations characterized by information sharing, consultation, and co-optation. However, what remains unclear is whether these insights, which are based on research performed in urban localities, can readily be transposed towards non-urban localities. Moreover, it is not always clear how power relations and competing political and economic interests between governmental and non-governmental actors determine local migration policies. To this end, we turn our attention to regime theory in urban and migration studies.

\subsection{A Regime-Theoretical Approach to Migration Governance in Rural Localities}

We take Bernt's (2019) argument that insights from regime theory in migration studies and urban studies can potentially inform one another, as a starting point to inform our theoretical approach.

The regime concept has a long history within urban studies that can be traced back to the "community power 
debate" (Harding, 2009). As Stone has argued, urban regimes are formed in response to situations of social change where "to be effective, governments must blend their capacities with those of various non-governmental actors" (1993, p. 6). Fragmentation of the capacity to act in response to social change thus motivates actors to erect urban regimes. A canonical example is Logan and Molotch's (1987, p. 53) "growth coalitions," referring to the forms of cooperation between rentiers, politicians, and other elites to intervene in the built environment to further the shared agenda of increasing economic growth. In our conceptualization of LMRs, we also consider how lacking institutional capacity and economic interests determine how governing coalitions form in Odemira.

While the previous insights could, in theory, be readily applied to the field of migration reception and integration, migration-related themes have not been of central concern in urban regime theories (Bernt, 2019 , p. 13). Instead, the regime concept has found widespread use in migration studies to refer to institutionalized modes of granting membership to immigrants (citizenship regimes), deterring and removing unwanted subjects from the state territory (deportation regimes), and international sets of rules and regulations around human mobility (migration regimes; Brubaker, 1992; De Genova, 2012). Despite these wildly varying meanings, the use of the regime concept in migration studies tries to "break free of state-centrism, to urge researchers to think about a multitude of actors and relationships" (Bernt, 2019, p. 11). Critical scholarship on migration governance "beyond the state" tends to adopt a broader conceptualization of "governmentality" that focuses on how power, political rationalities, and governing logics become dispersed across multiple actors and scales (see Ilcan \& Basok, 2004). For our purposes, it is particularly useful to keep in mind that the reception, management, and integration of PIWs is increasingly being outsourced to a variety of non-governmental organizations including private companies (see Ilcan \& Basok, 2004; Menz, 2011). Furthermore, the migration and governmentality literature has convincingly shown that state and non-state actors actively partake in the construction and reproduction of immigrant illegality and deportability (see De Genova, 2012; De Genova \& Peutz, 2010; Squire, 2011; Walters, 2015). What is not always specified in this literature, however, is how local governing coalitions emerge in the first place.

In this article, we combine insights from both traditions to explore emerging LMRs around the reception and integration of PIWs in Odemira. Building on Stone's classic definition (1989), we define LMRs as the formal and informal arrangements by which local public bodies and private interests function together in order to be able to make and carry out governing decisions around the reception and integration of immigrants. Initially, we expected LMRs in non-urban localities to be highly uneven and dominated by eco- nomic interests for three reasons. First, rural municipalities tend to lack the institutional capacity to accommodate PIWs and are therefore more inclined to turn to non-governmental actors to supply necessary knowhow and resources. Second, since economies in rural localities heavily depend on agriculture, private interests are bound to dictate LMRs. Third, since the political clout of local civil society-understood as the possibility to voice concerns and influence decision-making -in the field of migrant reception is less substantial in non-urban than in urban areas, criticisms can more easily be ignored by the governing coalition. In the sections below, we demonstrate how the emerging LMR in Odemira confirmed most of these expectations.

\section{Methodology}

\subsection{Research Design and Data Collection}

This study adopts a case study design to gain a better insight into the dynamics and characteristics of emerging LMRs in rural localities. More in particular, we focus on the emergence of governing coalitions around immigrant accommodation and integration in Odemira as a critical case (see Flyvbjerg, 2006). We rely on a combination of methods, including expert interviews and content analysis, to shed light on the underlying motivations and interests of public and private partners to join such coalitions (Bryman, 2016). By purposefully sampling representatives of the Parish Council, Odemira's Municipal Plan for Integration, agriculture workers' unions, work conditions inspection, and civil society organizations (respectively focused on immigrant rights, regional development, and environmental issues), we tried to map the positioning of the actors involved and the relations between them (Zapata-Barrero \& Yalas, 2018). An overview of the interviews can be consulted in the Supplementary File. Additionally, content analysis of policy documents, meeting records, and press releases was performed to check statements made in the interviews and fill in remaining gaps in our knowledge about the case. All interviews were conducted in Portuguese and transcribed and analyzed with NVivo.

\subsection{Contextualizing the Case}

Both economic and political factors need to be taken into consideration in order to contextualize the Odemira case.

From an economic perspective, the region suffers from a shortage of national workers available to work in the intensive agriculture sector. In demographic terms, the region of Odemira is characterized by its low population density, with on average 14.3 individuals per $\mathrm{km}^{2}$, as well as by its ageing population, with 238.9 elderly people per every 100 young people (PORDATA, 2018b, 2018c). However, the peculiarity of this municipality is that migration to the region has been increasing steadily 
since the intensive agriculture industry started growing (Fonseca, 2008). Between 2008 and 2014, the rate of variation/change of foreign population in the municipality of Odemira was $59.2 \%$, while at a national level the same rate was $-10.2 \%$ (Esteves et al., 2017). Furthermore, between 2014 and 2020 the foreign population in the municipality of Odemira tripled from 3,320 in 2014 to 9,615 in 2020 (SEFSTAT, 2020). This migration influx is clearly related to a regional specialization on intensive agriculture in combination with a lack of national workforce. The intensive agriculture industry in the region is specialized in red fruits, which is a type of agriculture that cannot be mechanized. According to the president of AHSA - an association of 30 agricultural companiesthere are 4,500 workers working in the intensive agriculture sector between the municipality of Odemira and a part of Algarve ("Covid-19: Produtores de Odemira," 2021). Agricultural work is generally considered to be physically tough and underpaid, which explains why Portuguese workers are not attracted to the sector. This in turn creates opportunities for migrant workers who are willing to accept these tough working conditionswithout disregarding the employers' interest in hiring cheap PIWs. The Portuguese Migration Observatory explains the labor situation in Odemira as follows:

The small local population, the low salaries, the harsh working conditions and the low social prestige of salaried work in agriculture in Portugal have led companies in the sector to temporarily or permanently hire foreign workers, either from EU28 countries (Romania, Bulgaria, for example) or from third countries, namely Asia. (Esteves et al., 2017)

From a political perspective, the Portuguese government took measures to provide more flexibility to companies to organize their businesses and attract and retain PIWs. In 2005, Portugal liberalized laws on the creation and dissolving of companies and cutting down on the bureaucratic paperwork involved (Ministério da Justiça, 2005). This liberalization created the possibility for less than transparent temporary work agencies to be legally conceived and dissolved rather quickly. The second liberalization process concerns national immigration laws. The 2017 amendment (Assembleia da República, 2017) to the immigration law 23/2007 (Assembleia da República, 2007) enabled immigrants to become regularized once they have a work contract and are registered in Social Security. In 2019, legal entry into the country became "assumed whenever the applicant has been working in the national territory and has had his or her social security situation in order for at least 12 months" (Assembleia da República, 2019).

\section{Findings}

Our research indicates that the emergence of a LMR in Odemira can be attributed to two main factors. On the one hand, the local government in Odemira was faced with an unprecedented challenge to accommodate and manage ILM that superseded their institutional capacity to act. Local constituencies grew increasingly worrisome about the social and cultural impact of PIW presence while available arrival infrastructures were lacking. On the other hand, agricultural businesses faced severe labor shortages that needed to be filled by securing a steady supply of cheap, flexible PIWs. Their efforts to support regularization and integration programs within the emerging LMR can therefore be seen as ways to promote their interests while aiding the local government to help manage the influx of PIWs in their municipalities. Below, we contextualize the case of Odemira, explore actors' perception of the local governance challenge that ILM poses, and analyze how public and private actors responded to this challenge.

\subsection{The Perception of International Labor Migration as a Local Governance Challenge}

In this section, we present how governmental and nongovernmental actors in Odemira perceive and evaluate the governance challenges posed by ILM in the region of Odemira. Based on our research, we identify three major areas that define PIW presence as a perceived policy problem. First, while attracting PIWs is important to secure labor supply for the agricultural sector, immigrant rights are severely lacking. Second, several respondents indicated that the socio-cultural impact of PIW presence in local communities like Odemira needs to be mediated. Third, the intensification of ILM to the region poses challenges for local public services and arrival infrastructures.

In economic terms, respondents stressed the need to sustain growth while opinions were more divided with regards to the impact the sector has on the environment, hiring practices, and precarious work conditions. The interviews revealed a clear consensus between public and private actors around the fact that the agricultural sector is economically beneficial and indispensable for the region. This position is perhaps most clearly articulated by the association of agricultural companies, who regards "this agricultural development as highly positive, bringing more jobs, wealth and better living conditions to the region, in a sustainable way and through a majority of companies with highly responsible social and environmental practices" (Interview 9). However, some respondents criticized the fact that the government is prioritizing economic growth while ignoring local impact. The president of the Parish Council of one of these villages expressed this as follows:

What we feel is an absence of the State. The State is in Lisbon and it is not worried. They want numbers, invoicing, values for the GDP growth. Impacts on the territory in environmental and social terms, they do not seem to be very interested in pursuing this matter. (Interview 1) 
Furthermore, agricultural hiring practices and the high turnover of the workforce were perceived as problematic by members of local civil society. The representative for an association for immigrant rights elaborated on the lack of interest from the employers to hire Portuguese workers: "Naturally, the companies themselves are not very interested in hiring Portuguese because they are more informed, they will complain to the Labor Court, Authority for Working Conditions, etc." (Interview 2). Economic migrants tend to stay for a short period of time, which makes the workforce rather unstable and hampers integration according to several respondents (Interviews 1, 6, and 7). Lastly, precarious work conditions of PIWs are perceived as problematic (Interviews 2, 3, and 7). "Service companies" operate as temporary work agencies that "sublet" the labor of their employees to different companies, thereby undermining their position:

In terms of stratification, I would say that those who have better conditions, both contractual and in terms of accommodation, are those who work directly for companies of reference; then, at an intermediate level, there would be workers who work for temporary work companies, but even so, already under worse conditions; and at the base of the pyramid, and that perhaps represents the majority, are workers who work for the service of "pseudo service providers companies," and where the most degrading working conditions are found. (Interview 7)

In political terms, all actors stressed mounting discontent among the citizenry about the social impact of PIW presence and the incapacity of local institutions to adequately manage ILM. A word often heard during the interviews was "quantity" - "the problem is the quantity" (Interview 1)-implying the number of immigrants is too high for what these villages can accommodate. The following quote from interview 1 serves as a good expression of how PIW presence is perceived as a sociocultural threat:

The ladies that used to go for a walk alone at the end of the day don't feel comfortable anymore because there are groups of foreign men walking around in groups of 10 or $12 . .$. Our cultural values have taken so many centuries to conquer... I feel that we are putting our social well-being at risk.

Negative discourses mainly focused on the perceived risk that the large number of immigrants might have on the values and habits of local communities. Another respondent expressed his concern with the identity of the region: "It is clear that an oversized migration influx which isn't planned, slightly compromises the identity of the region" (Interview 4). Conversely, positive opinions emphasize the role this immigration influx might play in repopulating these villages (see interviews 2,7 , and 9).
The perceived impact of PIW presence in rural localities is further exacerbated by the lack of arrival infrastructures. An important aspect of arrival infrastructures concerns suitable housing for PIWs. Due to the increasing housing demand, prices on the housing market have been on the rise. In this respect, respondent 6 states that "there is not enough accommodation for everybodya young couple looking for a house is going to have a lot of trouble finding it because most houses are being rented to migrants" (Interview 6). Some landlords prefer renting the houses to migrants, since migrants pay up to $100 €$ to $110 €$ per person (Interview 7). At the same time, the overcrowded houses, apartments, and establishments that PIWs are living in are often unsuitable to accommodate people. The working conditions inspector expressed this as follows:

If I tell you I have already counted 53 people living in a 3-bedroom apartment you may think it is a lie but it is not. In an old car shop I once found approximately 43 or 44 families living there, with mattresses piled up around the floor and only one bathroom. (Interview 7)

Respondent 3 added that the region is facing additional infrastructural problems since "there is not enough water pressure in the water pipes and telephone lines are often overcharged" (Interview 3). At the same time, respondent 4 explained that public services, such as social security, tax offices, and healthcare centers, are overloaded due to the increasing number of inhabitants:

Public services cannot handle the job, it's impossible to go to the tax office, to the social security or to the health care center, it's impossible. The publicly known fact that houses in Alentejo villages are being inhabited by dozens of people raises further questions about public health risks. (Interview 4)

\subsection{The Formation of Odemira's Local Migration Regime}

In the previous section, we outlined how local governments, agricultural companies, and civil society organizations found themselves grappling to respond to the rapidly changing character of economic and social life in rural localities in Odemira. In this section, we explain how a LMR was formed wherein public and private partners cooperated to produce policy measures aimed at securing growth and getting to grips with ILM. First, we outline how the LMR was formalized in publicprivate partnerships as reflected by the Municipal Plan for Integration and projects initiated by TAIPA-an organization that promotes the development of the municipality of Odemira. Next, we outline the projects and plans to remedy and mediate the triple governance challenge identified above.

The Municipal Plan for the Integration of Migrants in Odemira was developed between 2015 and 2017 by the 
impetus of the National Strategy for Migrant Integration of the high commissioner for migration. This plan, which is part of the Project Odemira Integra +, is funded by the Asylum, Migration and Integration Fund, and covers 10 operation fields. (Odemira Município, 2019). A representative of the Municipal Plan stressed that the participation of more than 40 entities in the conception, formulation, and execution of the strategy was of key importance:

The great added value of this Project has to do with the collaborative network that was created, the Project is not only of the municipality. Although the municipality is the coordinator... this would not be possible without the collaboration and participation of all entities. (Interview 5)

Subsequently, the Local Commission for Interculturality was created to serve as a platform where public entities like the parish councils, the public schools, Social Security, the Immigration and Borders Service and the Authority for Working Conditions and non-public entities like TAIPA, agricultural workers unions, and companies can meet (Interview 5). The platform aims to create "democratic practices, guided by local protagonism and based on horizontality, where local political decision makers are inserted, as partners" (Odemira Município, 2019). However, in practice, most of the heavy lifting is done through projects coordinated by TAIPA. As a TAIPA representative put it: "Everyone knows that TAIPA is the one who is on the ground and in the frontline in the immigration issue. It's either the municipality or TAIPA, or it comes from the municipality to TAIPA" (Interview 6). This was confirmed by the representative of the Municipal Plan, who stated that "TAIPA is a very strong partner here in the municipality" (Interview 5). Despite the horizontality that is put forward as a guiding principle within the public-private partnership, it can thus be argued that there is an imbalance within the governing coalition.

Since its inception, several initiatives and measures have been implemented by the governing coalition to address immigrants' precarious legal status, mediate socio-cultural impact, and develop arrival infrastructures.

First, the work of the Local Support Center for the Integration of Migrants from Odemira (CLAIM) exemplifies the effort by the governing coalition to improve the rights situation of PIWs through regularization. CLAIM is a project that has existed since 2014. Interestingly, the project has only been able to maintain its activities because of the joint funding by the municipality and large agricultural companies. CLAIM's main tasks are issues regarding legalization, family reunification and renewal of residence permits. In order to become regularized in Portugal, an immigrant needs to have a contract and a residence certificate from the Parish Council to prove the migrant lives in a certain locality. As explained above, it is in agricultural companies' interest that PIWs receive their legal status. The project has an office in S. Teotónio where immigrants take care of these issues. In addition, CLAIM has an "itinerary human resource officer" who travels between localities. Between July 2018 and December 2019, CLAIM performed 6,061 appointments and filed 3,645 applications (Taipa, 2019). The representative emphasizes this interaction as a positive aspect:

There are two sides here: on the one side we have the municipalities, the parishes, the local authorities and on the other side we have companies, which have different challenges. Because sometimes, as we know, it is difficult to combine the vision of a company, whose main purpose is profit, and of a local entity whose main purpose is the well-being of its population. Combining all this has been increasingly challenging lately, but these meetings, this intervention, this sharing, I think it ends up being the added value of this consortium. (Interview 6)

A representative of a union for agricultural workers stressed the important role CLAIM has in PIWs' legalization processes: "CLAIM is here to bridge the gap between immigrant workers and SEF [Immigration and Borders Services]" (Interview 3). A TAIPA representative confirmed this close relationship with SEF, stating that: "SEF itself calls CLAIM to clarify this or that document, meaning there is a direct connection" (Interview 6). According to respondent 7 , the joint efforts within the context of CLAIM have ensured that "today, talking about illegal immigrants is almost exaggerated" (Interview 7).

Second, projects and plans have been put in place by the local government as well as TAIPA to stimulate the integration of immigrants and improve the dialogue with the local community. The municipality's integration plan includes training public employees in public services, printing and disseminating the "Welcoming Kit for Migrant Citizens in Odemira," informing migrants about their tenant rights through the distribution of information materials on "Support for Housing Improvements" and "Support for Leasing," and celebrating Interculturality Day. In addition to CLAIM, TAIPA has two other projects dedicated to migrants: the S. Teotónio Project and the Giramundo Project. Since 2013, the S. Teotónio Project in the Parish of S. Teotónio is dedicated to "children, young people, and migrant families who have just arrived to establish a relationship with schools, facilitate integration at the school level and promote children's school success" (Interview 6). In addition, the project has a physical space, where school support is provided, Portuguese is taught, and more than 30 children of different nationalities attend daily after school. Since 2017, the Giramundo Project aims to improve the reception and integration of immigrants through cultural expressions and the promotion of dialogue with the local community. The project works directly with immigrants who take up a role as mediators: "We organize national days, they organize themselves, we are only facilitators. 
We have thematic awareness actions, road safety, maritime safety, citizenship, the environment" (Interview 6). For example, the initiative "À Descoberta do Concelho" (Discovering the Municipality) offers a tour of the municipality to newcomers with the goal of sharing gastronomic and local traditional experiences. According to the representative, the Giramundo Project has been successful at reaching out to the target group: "We have reached more than 2000 migrants in the last 2 years" (Interview 6).

Third, the governing coalition has adopted measures to provide temporary housing for PIWs. The aforementioned 2019 resolution allowed companies to install temporary housing containers for their workers in protected natural areas. As Fonseca et al. (2021, p. 8) recently argued, agricultural companies were able to lobby and pressure public authorities into classifying these containers as "complementary structures of farming activity" for a period of 10 years. Although far from a structural solution, this allowed businesses to protect their interests as to secure and retain the PIW labor force. Meanwhile, environmental activists criticized the way in which the government blatantly allowed companies to violate environmental laws:

This resolution of the Council of Ministers responded to the only obstacle to the growth of intensive agriculture. The only obstacle was the lack of housing for the workforce that is mostly foreign. As there was insufficient housing... for what this agricultural industry requires, the resolution allowed companies to install housing containers on the farms in the heart of the Natural Park to accommodate migrant workers to work in the agricultural industry. Almost as if considering a migrant worker to be an agricultural implement, in the end it is an accessory that they have to put inside the farms. (Interview 4)

Moreover, the unionist leader we interviewed questioned whether PIWs were actually better off with this "solution" to the housing problem offered by agricultural companies:

Companies... keep their passports, charge them a monthly fee and... they live in temporary housing containers, sometimes there are 17 people in a house without adequate provisions, the rent in some situations is taken directly from their salary... and some of them are working in inhumane conditions. (Interview 3)

\section{Conclusions}

The increased mobility of PIWs has created governance challenges for local governments, communities, and private actors alike around the world. Existing scholarship has largely focused on how cities are taking up a leading role as active agents within multi-level governance arrangements around the reception and integra- tion of immigrants (see Schiller, 2016; Zapata-Barrero et al., 2017). In this article, we argue that more attention needs to be paid to the characteristics and dynamics of such arrangements in non-urban localities. The findings of our case study in Odemira suggest that both global forces-relating to the globalization of agricultural production and the need to secure a steady supply of flexible labor-and local forces-relating to the incapacity of local governments in rural areas to tackle issues of immigrant integration by themselves-shape these dynamics. We build on and combine insights from urban and migration studies to suggest that the formal and informal arrangements that emerge in Odemira between local public bodies and private interests around the question of immigrant reception, can best be understood as emerging LMRs. Our case study suggests that Odemira's LMR is characterized by a high degree of collaboration and cooperation between the local government and agricultural companies in the form of public-private partnerships. The coordinated interaction between TAIPA and the municipality enables them to share resources and information. This insight thus confirms the findings of recent scholarship on local migration governance, which suggests that immigration policies are increasingly being developed through cooperation and coproduction between actors in local settings (see De Graauw, 2016; Schiller, 2016).

However, we argue that the finality and make-up of the LMR in Odemira exhibits several characteristics that are specific to non-urban settings. As exemplified by the financing of the initiative CLAIM by agricultural companies, there is an unusual agreement between partners in the LMR about the need to facilitate the regularization of PIWs' legal status. Although scholarship on sanctuary city policies (see De Graauw, 2016) has shown how civil society organizations play a crucial role in pressuring local governments to adopt inclusive measures towards PIWs, this explanation does not hold in the case of Odemira. Compared to the strength and presence of civil society in urban settings, it can be argued that local immigrant rights associations in a rural area like Odemira lack teeth. Furthermore, the fact that CLAIM is financed by the private sector not only reveals the strategic importance of this project to the companies involved, but also the highly uneven distribution of resources between partners in the LMR. Despite the consensus around the need to improve the accommodation and legal status of PIWs, no significant steps are undertaken to improve their worker rights or marginalized socio-economic position. This begs the question whether the "inclusive" policy arrangements initiated by partners in the LMR do little more than securing a steady supply of-relatively better accommodated-cheap immigrant labor while appeasing discontent among citizens about the social and cultural impact of PIW presence.

The findings from this case study open up various promising pathways for future research. First, in order to have a more in depth-understanding of the impact of 
emerging LMRs on PIWs' rights, it seems indispensable to do protracted fieldwork to further document how they experience and act upon the legal and socio-economic precarity they face (see Swerts 2020). Second, comparative research could reveal how the dynamics and characteristics of LMRs vary between urban and non-urban localities while paying attention to the changing relationalities and political rationalities of public-private partnerships. Third, due to the exploratory and interviewbased nature of this research, relatively more emphasis has been placed upon formal governance arrangements. Therefore, gaining more insight into the more informal practices and arrangements that uphold LMRs could help provide a complete picture of how formal arrangements come into being. If anything, this study underscores the importance for scholars, policy makers, and practitioners committed to advancing the rights and social position of PIWs to widen their gaze beyond the city and expand collective action and reflection to rural areas.

\section{Acknowledgments}

We would like to thank all the respondents who have participated in this study.

\section{Conflict of Interests}

The authors declare no conflict of interests.

\section{Supplementary Material}

Supplementary material for this article is available online in the format provided by the author (unedited).

\section{References}

Assembleia da República. (2007). Lei no 23/2007 [Law no. 23/2007]. Diário da República. https://dre.pt/ pesquisa/-/search/635814/details/maximized

Assembleia da República. (2017). Lei n.o 59/2017 [Law no. 59/2017]. Diário da República. https://dre.pt/ home/-/dre/107781373/details/maximized

Assembleia da República. (2019). Lei no 28/2019 [Law no. 28/2019]. Diário da República. https://dre.pt/ pesquisa/-/search/121712771/details/maximized

Bauder, H. (2017). Sanctuary cities: Policies and practices in international perspective. International Migration, 55(2), 174-187.

Bernt, M. (2019). 'Urban regimes' and 'migration regimes': Contradictions, connections and potentials. Erdkunde, 73(1), 9-17.

Brubaker, W. R. (1992). Citizenship and nationhood in France and Germany. Harvard University Press.

Bryman, A. (2016). Social research methods. Oxford University Press.

Cole, J. E., \& Booth, S. S. (2007). Dirty work: Immigrants in domestic service, agriculture, and prostitution in Sicily. Lexington Books.
Covid-19: Produtores de Odemira alertam para "impacto económico" da cerca sanitária [Covid-19: Odemira's producers warn of "economic impact" of local lockdown]. (2021, April 30). Agência Lusa. https:// www.lusa.pt/article/NGNuPZmpRYTuWSuQ6atc6DM SZM5iuSI1/covid-19-produtores-de-odemiraalertam-para-impacto-econ\%C3\%B3mico-da-cercasanit\%C3\%A1ria

De Genova, N. (2012). Migrant "Illegality" and deportability in everyday life. Annual Review of Anthropology, 31(1), 419-447.

De Genova, N., \& Peutz, N. (2010). The deportation regime: Sovereignty, space, and the freedom of movement. Duke University Press.

De Graauw, E. (2016). Making immigrant rights real: Nonprofits and the politics of integration in San Francisco. Cornell University Press.

De Graauw, E., \& Bloemraad, I. (2017). Working together: Building successful policy and program partnerships for immigrant integration. Journal on Migration and Human Security, 5(1), 105-123.

Dias, C. (2019, March 17). Odemira já mal respira sob o plástico das estufas [Odemira barely breathes under the greenhouses' plastic]. Público. https://www.publico.pt/2019/03/17/local/noticia/ culturas-intensivas-vieram-agravar-realidadeambiental-social-concelho-odemira-1864562

Esteves, A., Estevens, A., Amílcar, A., MCGarrigle, J., Malheiros, J., Moreno, L., Fonseca, M. L., \& Pereira, S. (2017). Condições de vida e inserção laboral de imigrantes em Portugal: Efeitos da crise de 2007-2008 [Living conditions and labour insertion of imigrants in Portugal: Effects of the 2007-2008 crisis]. Observatórios das Migrações.

Faget, J. (2018, March 19). Illegal immigrants provide cheap labor in Portugal's agricultural sector. Deutsche Welle. https://www.dw.com/en/illegalimmigrants-provide-cheap-labor-in-portugalsagricultural-sector/a-43039465

Flyvbjerg, B. (2006). Five misunderstandings about casestudy research. Qualitative Inquiry, 12(2), 219-245.

Fonseca, M. L. (2008). New waves of immigration to small towns and rural areas in Portugal. Population, Space and Place, 14(6), 525-535. https://doi.org/10.1002/ psp. 514

Fonseca, M. L., Esteves, A., \& Moreno, L. (2021). Migration and the reconfiguration of rural places: The accommodation of difference in Odemira, Portugal. Population, Space and Place. https://doi.org/ 10.1002/psp.2445

Goldring, L., \& Landolt, P. (2012). The impact of precarious legal status on immigrants' economic outcomes. IRPP Study.

Goldring, L., \& Landolt, P. (2021). From illegalised migrant toward permanent resident: Assembling precarious legal status trajectories and differential inclusion in Canada. Journal of Ethnic and Migration Studies. Advance online publication. https://doi.org/ 


\section{$10.1080 / 1369183 X .2020 .1866978$}

Harding, A. (2009). The history of community power. In J. S. Davies \& D. L. Imbroscio (Eds.), Theories of urban politics (pp. 27-39). SAGE.

Ilcan, S., \& Basok, T. (2004). Community government: Voluntary agencies, social justice, and the responsibilization of citizens. Citizenship Studies, 8(2), 129-144.

Lambert, S., \& Swerts, T. (2019). From sanctuary to welcoming cities': Negotiating the social inclusion of undocumented migrants in Liège, Belgium. Social Inclusion, 7(4), 90-99. https://doi.org/10.17645/si. v7i4.2326

Logan, J., \& Molotch, H. (1987). Urban fortunes: The political economy of place. University of California Press.

Martin, P. (1983). Labor-intensive agriculture. Scientific American, 249(4), 54-59.

Meeus, B., Arnaut, K., \& van Heur, B. (2019). Arrival infrastructures: Migration and urban social mobilities. Palgrave Macmillan.

Menz, G. (2011). Neo-Liberalism, privatization and the outsourcing of migration management: A fivecountry comparison. Competition \& Change, 15(2), 116-135.

Ministério da Justiça. (2005). Decreto-Lei n.o 111/2005 [Decree-Law no. 111/2005]. Diário da República. https://dre.pt/pesquisa/-/search/235906/details/ maximized

Odemira Município. (2019, January 17). Odemira Integra +, Plano Municipal para a Integração de Migrantes (2018-2020) [Odemira Integra +, Municipal Plan for the Integration of Migrants (2018-2020)]. https://www.cm-odemira.pt/pages/1100

Peixoto, J. (2002). Strong market, weak state: The case of recent foreign immigration in Portugal. Journal of Ethnic and Migration Studies, 28(3), 483-497.

Pereira, S., Moreno, L., Estevens, A., Esteves, A., \& Malheiros, J. (2016). Reconfiguración de áreas rurales y explotación de mano de obra inmigrante: el caso de Odemira, Portugal [Reconfiguration of rural areas and the exploitation of migrant labour: the case of Odemira, Portugal]. Centro de Estudios Migratorios Latinoamericanos, 81, 227-250.

Piore, M. J. (1979). Birds of passage. Cambridge University Press.

PORDATA. (2018a). População residente, estimativas a 31 de Dezembro [Resident population, 31 December estimates] [Data set]. https://www.pordata.pt/ Municipios/Popula\%C3\%A7\%C3\%A3o+residente+ +estimativas+a+31+de+Dezembro-120

PORDATA. (2018b). Densidade populacional [Population density] [Data set]. https://www.pordata.pt/ Municipios/Densidade+populacional-452

PORDATA. (2018c). Índice de envelhecimento [Aging index] [Data set]. https://www.pordata.pt/ Municipios/\%c3\%8dndice+de+envelhecimento-458

Reyneri, E. (2004). Immigrants in a segmented and often undeclared labour market. Journal of Modern Italian Studies, 9(1), 71-93.
Robinson, G. (2018). Globalization of agriculture. Annual Review of Resource Economics, 10(1), 133-160.

Sampaio, D., \& Carvalho, R. F. (2016). From the AlMaghrib to the Al-Gharb: An anatomy of the recruitment and labour incorporation of Moroccan agricultural workers in the Algarve, Southern Portugal. In A. Corrado, C. de Castro, \& D. Perrotta (Eds.), Migration and agriculture (pp. 255-269). Routledge.

Sassen-Koob, S. (1981). Towards a conceptualization of immigrant labor. Social Problems, 29(1), 65-85.

Schiller, M. (2016). European cities, municipal organizations and diversity: The new politics of difference. Palgrave Macmillan.

Schiller, M. (2018). The local governance of immigrant integration in Europe: The state of the art and a conceptual model for future research. In T. Camponio, P. Scholten, \& R. Zapata-Barrero (Eds.), The Routledge handbook of the governance of migration and diversity in cities (pp. 204-215). Routledge.

SEFSTAT. (2020). População estrangeira residente em Portugal 2008-2020 [Foreign population living in Portugal 2008-2020] [Data set]. https://sefstat.sef.pt/ forms/distritos.aspx

Squire, V. (2011). The contested politics of mobility: Borderzones and Irregularity. Routledge.

Stone, C. N. (1989). Regime politics: Governing Atlanta, 1946-1988. University Press of Kansas.

Stone, C. N. (1993). Urban Regimes and the Capacity to Govern. Journal of Urban Affairs, 15, 1-28.

Swerts, T. (2020). Power and empowerment. In H. F. Wilson \& J. Darling (Eds.), Research ethics for human geography: A handbook for students (pp. 59-66). SAGE.

Swyngedouw, E. (2019). Governing newcomers' conduct in the arrival infrastructures of Brussels. In B. Meeus, K. Arnaut, \& B. van Heur (Eds.), Arrival Infrastructures. Palgrave Macmillan. https://doi-org.eur.idm. oclc.org/10.1007/978-3-319-91167-0_4

Swyngedouw, E. (2020). Reeling in newcomers: Urban competition around migrant reception in Brussels. International Journal of Urban and Regional Research, 44(3), 395-414.

TAIPA. (2019). CLAIM Odemira info [Brochure]. TAIPA.

Thornley, C., Jefferys, S., \& Appay, B. (2010). Globalisation and precarious forms of production and employment: Challenges for workers and unions. Edward Elgar.

Walters, W. (2015). On the road with Michel Foucault: Migration, deportation, and viapolitics. In S. Fuggle, Y. Lanci, \& M. Tazzioli (Eds.), Foucault and the history of our present (pp. 94-110). Houndmills.

Wimmer, A., \& Glick-Schiller, N. (2002). Methodological nationalism and beyond: Nation-state building, migration and the social sciences. Global Networks, 2, 301-334.

Zapata-Barrero, R., Caponio, T., \& Scholten, P. (2017). Theorizing the 'local turn' in a multi-level governance framework of analysis: A case study in immigrant poli- 
cies. International Review of Administrative Sciences, 83(2), 241-246.
Zapata-Barrero, R., \& Yalaz, E. (Eds.). (2018). Qualitative research in European migration studies. Springer.

\section{About the Authors}

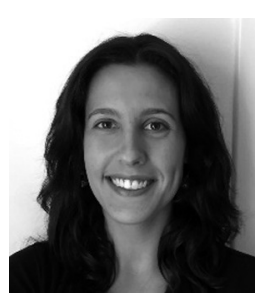

Inês Cabral is a MSc graduate in sociology at the Department of Public Administration and Sociology of the Erasmus University Rotterdam. Her research focused on the reception and societal impact of rural labour migration in the municipality of Odemira. Previously she studied International Relations at the University of Lisbon.

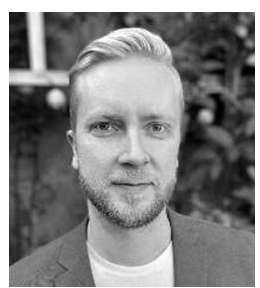

Thomas Swerts is an assistant professor in sociology at the Department of Public Administration and Sociology of the Erasmus University Rotterdam. He previously received his PhD in sociology from the University of Chicago. For his dissertation research, he performed an ethnographic study of undocumented activism in the US and Europe. His research focuses on the nexus between irregular migration, political sociology, and urban studies. He has contributed to edited volumes on citizenship studies, immigrant rights mobilization, and relational poverty politics. 